\title{
Isolation and Molecular Characterization of a Variant Infectious Bronchitis Virus in Kafrelsheikh, Egypt During 2016
}

\author{
Asmaa Magouz ${ }^{1}$, Gabr Elbagoury ${ }^{2}$, Shimaa Ayoub ${ }^{3}$ \\ ${ }^{1,3}$ Department of Virology, Faculty of Veterinary Medicine, Kafrelsheikh University, 33516, Egypt \\ ${ }^{2}$ Department of Virology, Faculty of Veterinary Medicine, Banha University
}

\begin{abstract}
Infectious bronchitis (IB) is a major disease affecting chickensall over the world. The present study was designed for isolation and molecular characterization of IB viruses circulating among different regions in Kafrelsheikh province, Egypt. Twenty two field samples were collected from broiler chicken flocks.The collected samples were propagated in the allantoic cavity of embryonated chicken eggs. The isolated strains were characterized by polymerase chain reaction (PCR) through amplification of S1gene followed by sequence analysis of one isolate. Egg inoculation revealed dwarfing with characteristic curling appearance. PCR assay shows 10 positive field samples and phylogenetic analysis revealed the closest relationship with the Israel variant strain IS/1494/06.
\end{abstract}

Keywords: IBV, Egypt, Kafrelsheikh, S1 gene.

\section{Introduction}

Acute upper-respiratory diseases in chickens aremajor causes of economic lossesthroughout the world due to high mortality ratesespecially in poorly managed cases (Yashpal et al., 2004). Infectious bronchitis (IB)is an acute highly contagious, worldwide distributed viral disease of chickens caused by infectious bronchitis virus (IBV) (Jahantigh et al., 2013). IBV affects chickens of all ages, causing respiratory and renal symptoms (Cook et al., 2012). The disease commonly causes respiratory manifestationssuch as coughing, sneezing, rales, and nasal discharge, (El-Mahdy et al., 2011). In addition, some nephropathogenic strains of IBVlead tosevere kidney lesions (Pohuang et al., 2009).

In Egypt, IB infection was first recognized during 1950s by Ahmed, 1954from birds with respiratory distress with the isolation of a variant resembling the Dutch variant D3128(De Wit et al., 2011). Later, isolates closely related to D274, Massachusetts, D-08880, 4/91, Egypt/Beni-Suef/ 01 and the Israeli variant were isolated from different Egyptian provinces (Abdel-Moneim et al., 2006e. The IB viral particles are corona shaped about $120 \mathrm{~nm}$ in diameter with club-shaped surface spikes. (El-Shafey2008).

Viral genome is a positive-sense RNA of about $27.6 \mathrm{~kb}$ in overall size. IBV encodes four structural proteins, the spike (S) glycoprotein, the membrane (M) glycoprotein, the nucleocapsid $(\mathrm{N})$ protein and the envelope (E) protein (Mo et al., 2013). ManyIBV serotypes have been isolated worldwide, e.g. Connecticut, Massachusetts (Mass), 4/91, D274, H120, Baudetteand California with low or even nocross protection between eachother (Roussan et al., 2008). The spike (S) glycoprotein gene consists of twosubunits, S1 and S2. S1 is frequently used for PCR and sequencing due to its high variability which can reach up to $50 \%$ in amino acid sequence between IBV serotypes(Patel et al., 2015). Thus, accurate diagnosis of the exact serotype identity circulating in chicken farms in Egypt is very essential for modifying the effective vaccination program to get overIB outbreaks in Egypt (Mahgoub et al., 2010).Controlling IB disease is a great challengebecause of the huge variations in the serotypes which emerge from time to time. (El-Mahdy et al., 2010).

In this study we report the isolation and molecular characterization of a nephropathogenicIB virus isolated from chicken flocks in Kafrelsheikhprovince during the period fromJanuary 2015 till March 2016.

\section{Material and Methods}

\subsection{Source and collection of samples}

A total of 22 tissue samples (lung, tracheaand kidneys)were collectedfrom chicken flocks in Kafrelsheikh province experiencing respiratory manifestations and high mortality rates during the period fromJanuary 2015 till March 2016.The samples werestored at $-80^{\circ} \mathrm{C}$ till processed.

\subsection{Virus isolation}

Samples from the same flocks were pooled and grinded to prepare $10 \%$ tissue suspensions in PBS (pH 7.2) solution containing Penicillin (1 million IU/L) and Gentamycin (250 $\mathrm{mg} / \mathrm{L})$. It was centrifuged at 10,000 for $15 \mathrm{~min}$ at $4^{\circ} \mathrm{C}$ and the supernatant fluid was inoculated into three 9-11- days old SPF embryonated chicken eggs via the allantoic cavity route. The eggs were incubated at $37^{\circ} \mathrm{C}$ for $4-7$ days and were daily examined.

\subsection{Identification of the isolated viruses by PCR}

- RNA extraction

RNA was extracted from infected allantoic fluid using Trizol Easy-Red $^{\mathrm{TM}}$ Total RNA extraction Kit (Intron Biotechnology) as per manufacturer's protocol. Briefly, 350 $\mu \mathrm{l}$ of allantoic fluid were mixed with $750 \mu \mathrm{l}$ of Trizol 


\section{International Journal of Science and Research (IJSR) \\ ISSN (Online): 2319-7064 \\ Index Copernicus Value (2015): 78.96 | Impact Factor (2015): 6.391}

reagent then centrifuged at $13,000 \mathrm{rpm} / 5 \mathrm{~min}$. The supernatant was transferred to a fresh DEPC treated tube and added with $200 \mu \mathrm{l}$ of cold chloroform. Then centrifuged at $13,000 \mathrm{rpm} / 10 \mathrm{~min}$ at $4^{\circ} \mathrm{C}$. $500 \mu \mathrm{l}$ of chilled isopropanol was added to the upper aqueous phase then centrifuged at $13,000 \mathrm{rpm} / 5 \mathrm{~min}$ at $4^{\circ} \mathrm{C}$. The supernatant was discarded and the pellet was washed with $70 \%$ cold ethanol. The pellet was re-suspended in $30 \mu \mathrm{IRNAse}$ free water and stored at $80^{\circ} \mathrm{C}$ till used

\section{- Reverse transcription of extracted RNA to CDNA}

The reverse transcription (RT) reaction was performed using Maxime ${ }^{\mathrm{TM}}$ RTPreMix Kit (Gene On) with specific primers as per manufacturer's protocol. Briefly, $5 \mu \mathrm{l}$ of RNA, $1 \mu \mathrm{l}$ of specific primer and $2 \mu 1$ of RNAs free water were added in a DEPC treated tube and incubated at $70{ }^{\circ} \mathrm{C}$ for $5 \mathrm{~min}$. Then kepton ice for $5 \mathrm{~min}$. Another mixture of $4 \mu \mathrm{l} 5 \mathrm{X}$ reaction buffer, $1 \mu \mathrm{l}$ dNTP mix , $1 \mu$ RNAs inhibitor, $1 \mu \mathrm{l}$ MMLV Reverase $(200 \mathrm{u} / \mu \mathrm{l})$ and $13 \mu \mathrm{l}$ RNAse free water. Mix I and II were combined together, vortexed and incubated at $50^{\circ} \mathrm{C}$ for $60 \mathrm{~min}$, then at $70^{\circ} \mathrm{C}$ for $5 \mathrm{~min}$. cDNA was stored at $20^{\circ} \mathrm{C}$ till used.

\section{- $\mathrm{PCR}$ reaction}

Primers that specifically amplify IBV (S1 gene) werecommercially synthesized (Metabion international AG, Germany) and are shown in table 1.

Table 1: Nucleotide sequences of S1 gene primer used in this study.

\begin{tabular}{|l|l|l|l|l|}
\hline Primer & Oligonucleotide sequence & gene & bp & Reference \\
\hline Co1 & TGACTCTTTTGTKTGCACTAT & S1 gene & 403bp & Farsang et.al 2002 \\
Co2 & AAATTATAATAACCACTCTGA & & & \\
\hline
\end{tabular}

The PCR reaction mixture consisted of $12.5 \mu \mathrm{l}$ of (Taq DNA Polymerase 2X-preMix ${ }^{\mathrm{TM}}$, GeneON) $1 \mu \mathrm{l}$ of forward and reverse primers, $3 \mu \mathrm{l}$ of cDNA and $7.5 \mu \mathrm{l}$ of PCR grade water. The thermal conditions consisted of initial denaturation at $95^{\circ} \mathrm{C} / 5 \mathrm{~min}$ then 35 cycles of denaturation at $95^{\circ} \mathrm{C} / 45 \mathrm{sec}$, annealing at $55^{\circ} \mathrm{C} / 1 \mathrm{~min}$ and extension at $72^{\circ} \mathrm{C} / 1 \mathrm{~min}$ then final extension at $72^{\circ} \mathrm{C} / 10 \mathrm{~min}$. A sample with only primers andPCR grade water was used as a negative control.

- Detection of PCR product by gel electrophoresis Amplified PCRproducts were visualizedunder ultraviolet light afteragarose gel electrophoresis using $1.5 \%$ agarose and staining with $0.1 \mu \mathrm{g} / \mathrm{ml}$ ethidium bromide.

\subsection{Sequencing and phylogenetic analysis}

The nucleotide sequence data of our isolate IBV/KFS/2016 was submitted to the GenBank sequence database and have been assigned the accession number KY072832.

Resulting sequences were analyzed using the nucleotide Basic Local Alignment Sequence Tools (BLASTn) and the multiple sequence alignment programs (ClustalW) using reference GenBank sequences .Phylogenetic tree was constructed via multiple alignments of $403 \mathrm{bp}$ nucleotide sequence of our isolate (IBV/KFS/2016) using the neighbor -joining (N-J) tree method using the MEGA version 6 software.

\section{Results}

\subsection{Virus isolation}

The inoculated ECE were daily examined and embryo mortality was recorded. Embryonic deaths occurred between 3-5 days post inoculation with characteristic stunting and curling of embryos after applying three blind egg passages as shown in Fig.1.

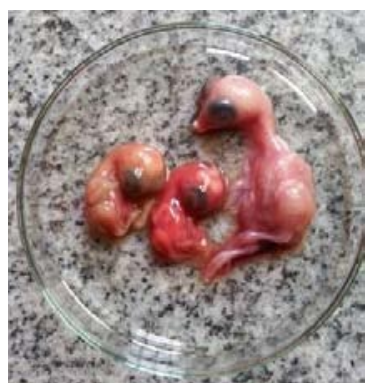

Figure 1: Stunting and curling of embryos infected with IBV (right) compared to a normal non inoculated embryo (left).

\subsection{Identification of the isolated viruses by PCR}

The collected allantoicfluids wereexamined for the presence ofIBV virusthroughamplification of the S1 geneusing specificprimers.Results revealed that 10samples were positive for IBV as they show amplification of specific band (403bp) as shown in Fig 2.

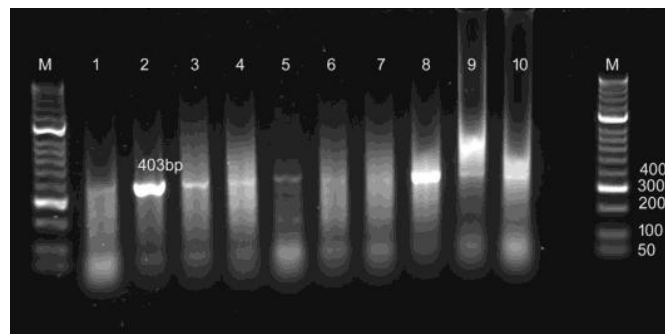

Figure 2: Positive amplification of specific bands of S1 gene of 10 field samples (403bp).

\subsection{Sequencing and phylogenetic analysis}

S1 sequence analysis of our isolate IBV/KFS/2016 (KY072832) revealed its close relatedness to IBVEG/13280F-SP1-2013(KU979008.1),Eg/CLEVB-2/IBV/012 (JX173488.1) serotypes and the Israelian strains IS/1494/06 (EU780077.2), IB VAR2-06 (JX027070.1) and Israel/720/99 (AY091552.2) as shown in table 2 and Fig. 3. 


\section{International Journal of Science and Research (IJSR) \\ ISSN (Online): 2319-7064}

Index Copernicus Value (2015): 78.96 | Impact Factor (2015): 6.391

Table 2. Nucleotide and amino acid identities of the isolate IBV/KFS/2061 (KY072832) compared with other Genbank located reference strains.
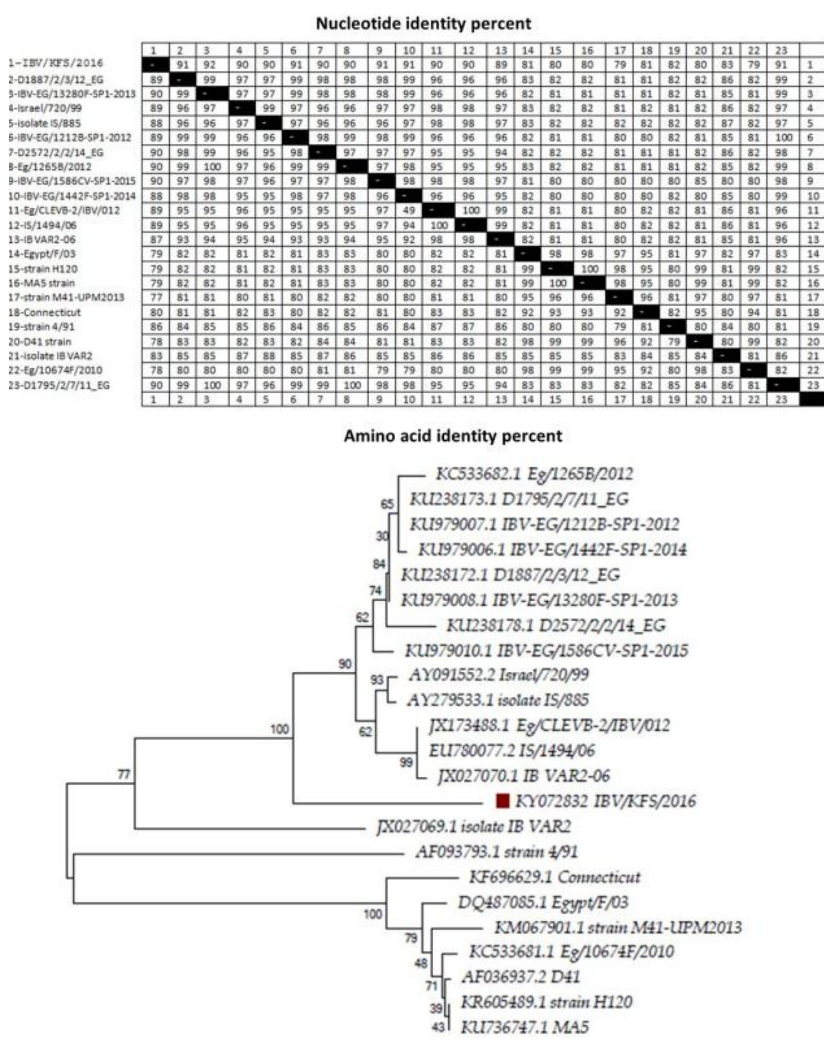

Figure 3: Phylogenetic analysis of IBV/KFS/2061

(KY072832) isolated from Kafrelsheikh province, Egypt, based on partial S1 gene nucleotide sequences with Genbank located reference sequences.

\section{Discussion}

Infectious bronchitis disease is one of the main causes of respiratory disease in chicken worldwide leading to severe economic losses to the poultry section(Broomand et al., 2012). IBVis endemic inmost of poultry sites, with a mortality rate reaching up to $100 \%$ while mortalities differs from $20 \%$ to $30 \%$ or even more and these arecommonly due to mixed infections with other pathogens such as Mycoplasmaand E coli.Mortalities of up to $25 \%$ are reportedin young chicks affected nephritis caused by other IBV serotypes (IgnjatovicandSapats2000).

In the current study, we report the isolation of an Egyptian IBV isolate; IBV/KFS/2016 from chicken flocks experiencingrespiratory and renal symptoms with relatively high mortality rates. The virus was isolated from Kafrelsheikhprovince in the Northern part of Egypt. All the collected samples were inoculated into ECE and confirmed by PCR analysis.

Inoculation of tissue suspensions of the collected samples in SPF chicken eggs resulted in stunted growth of the embryos which agreed withCook et al., 2012 who showed that the best method of IBV isolation is to passage a sample in 9-11day-old embryonatedSPF chicken eggs via the allantoic cavity route. The virus causes characteristic stunting and curling of the embryo after 5-7 days post inoculation.Due tothe great similarity in the symptomsof upper respiratory diseases, rapid and accurate diagnostic methods for identification of the causative pathogens should be applied (Rafiei et al., 2009).PCR test is the most sensitive and fast test for the identification of infections from clinical specimens which mayshow negative results due to improper sampling technique or loss of viral infectivity during transportation(Vapret et al.,2000). The positive samples were confirmed as IBV through PCR assay which resulted in a 403 bp product by using specific S1 primers. Only 10/22 of the samples were confirmed as IB viruses.Although, the increased mortality that associated with the disease described here, might be due to additional factors which increased the severity such as mixed infection with other pathogens as AIV, NDV, E coli or Mycoplasma.

Nucleotide sequence variation in S1 gene is commonly used for recognizingdifferent IBV serotypes as the emergence of new variants is the result of few amino acid changes in the S1 glycoprotein leading to sever outbreaks (Abdel-Moneim et al 2006).

In Egypt, IBV variants have been recognized firstly in $1950 \mathrm{~s}$ by isolation of a variant closely related to the Dutch variant D3128 (A. Ballal et al, 2005). While in 2006 Abdelmoneim et al, 2006 isolated an Egyptian strain of IBV 'Egypt $\backslash \mathrm{F} / 03$ ' which was closely related to the Massachusetts, H120, Beaudette-US, and M41 serotypes.

S1 sequence analysis of our isolate IBV/KFS/2016 (KY072832) revealed its close relatedness to IBVEG/13280F-SP1-2013(KU979008.1 ) ( 92\% nucleotide and90\% amino acid identities),Eg/CLEVB-2/IBV/012 (JX173488.1 ) (90\% nucleotide and 89\% amino acid identities) serotypes and the Israelian strains IS/1494/06 (EU780077.2) (90\% nucleotide and $89 \%$ amino acid identities), IB VAR2-06 (JX027070.1 ) (90\% nucleotide and $87 \%$ amino acid identities)and Israel/720/99(AY091552.2 ) (90\% nucleotide and $89 \%$ amino acid identities). While it but was clearly different from that of the H120 (KR605489.1), MA5 (KU736747.1) (80\% nucleotide and $79 \%$ amino acid identities), and 4/91(AF093793.1) (82\% nucleotide and $86 \%$ amino acid identities)vaccinal strains commonly used in Kafrelsheikh province which explains the frequent vaccination failure.Theseresults are in agreement with Susan et al,2010 and Selima et al, 2012, who isolated an IBV strain closely related to the Israeli Variant-2 and IS/1494/06 strains. In addition, Awad et al., 2014 have characterized seven IBV field isolates which exhibited high nucleotide sequence similarity to variant 2 like strains; IBV-CU-2-SP1 and $\mathrm{Eg} / 12120 \mathrm{~s} / 2012$. These isolates come close to a new variant group which is suspected to be the primary cause for IBV outbreaks in Egypt.

Conclusion from this study is that IBV variant 2 emergences has been reported to be circulating in Egypt and playing an important role in IBV outbreaks in the Middle East and Egypt. To provide sufficient protection against IBV, vaccination should be applied with the homologous serotype, as vaccination with a live attenuated heterologous 


\section{International Journal of Science and Research (IJSR) \\ ISSN (Online): 2319-7064 \\ Index Copernicus Value (2015): 78.96 | Impact Factor (2015): 6.391}

strain will provide insufficient and incomplete protection (Xie et al.2011). Thus, it is necessary to apply scheduled diagnosis of newly originating IBV strains for modifying a successful vaccination program to avoid and control new IBV outbreaks.

\section{References}

[1] Abdel-Moneim, A. S., El-Kady, M.F.,Ladman, B.S., Jack Gelb, J.,2006.S1 gene sequence analysis of a nephropathogenic strain of avian infectious bronchitis virus in Egypt Virology Journal, 3, 78.

[2] Ahmed, H.N.,1954. Incidence and treatment of some infectious viral respiratory diseases of poultry in Egypt.Ph.D.Thesis, Fac. Vet. Med. Cairo University, Giza, Egypt.

[3] Awad,A. M.,SediekM.E.,El-Yamany M. E.,2014.Isolation and Molecular Characterization of Novel IBV Isolates from Broiler Chicken Farms in Egypt.Alexandria journal of veterinary Sciences, 42, 7482.

[4] Ballal, A., Karrar,A., El-Hussein, A.,2005.Isolation and characterization of infectious bronchitis virus strain 4/91 from commercial layer chickens in the Sudan Journal of Animal VeterinaryAdvanced, 4, 910-912.

[5] Broomand,C.H., Aini,I., Abdulrahman, O., Khatijah, Y.,Shrifah, S.H.,2007.Development of multiplex RT-PCR for rapid detection and subtyping viruses type A .Proceedings of the 12th International Conference of the Association of Institutions of Tropical Veterinary Medicine - Montpellier, France 2007.

[6] Cook, J.K.,Jackwood, M., Jones, R. C., 2012.The long view: 40 years of infectious bronchitis research, Avian Pathology, 41, 239-250.

[7] De Wit,S. J., Cook, J. K.,Van der Heijden H. M.,2011. Infectious bronchitis virus variants: a review of the history, current situation and control measures Avian Pathology 40, 223-235.

[8] El-Mahdy, S.S., Ekram, S., Ahmed, A.,2010. Efficacy of some living classical and variant infectious bronchitis vaccines against local variant isolated from Egypt, Natural and Science, 10, 292-299.

[9] El-Shafey,A.M.,2008.Advanced study on infectious bronchitis of chicken in Egypt.Phd Thesis, Zagazig University.

[10] Farsang, A., Ros C., RenströmL.H., M., Baule, C., Soós, T.,Belák S.,2002.Molecular epizootiology of infectious bronchitis virus in Sweden indicating the involvement of a vaccine strain, Avian Pathology, 31, 229-236.

[11] Ignjatovic, J. , Sapats, S.,2000.Avian infectious bronchitis virus. RevueScientifiqueEt Technique.19, 493-508.

[12] Jahantigh, M.,Salari, S.,Hedayati, M., 2013. Detection of infectious bronchitis virus serotypes by reverse transcription polymerase chain reaction in broiler chickens Springerplus 2, 36.

[13] Mahgoub, K.M., Bassiouni, A.A. ,Afify,M.A. ,Rabie,N.S.,2010.The Prevalence of Infectious Bronchitis (IB) Outbreaks in Some Chicken Farms. I. Spotlight on the Status of IB Outbreaks in Some Chicken Flocks.Journal of American Science ,6, 57-70.
[14] Mo, M.L., Hong, S.M., Kwon, H.J., Kim, I.H., Song, C.S., Kim, J.H., 2013."Genetic Diversity of Spike, 3a, $3 \mathrm{~b}$ and $\mathrm{E}$ Genes of Infectious Bronchitis Viruses and Emergence of New Recombinants in Korea. Viruses 5, 550-567.

[15] Patel,B., Bhimani,M., Bhanderi, B. , Jhala,M., 2015. Isolation and molecular characterization of nephropathic infectious bronchitis virus isolates of Gujarat state, India. Virusdisease, 26, 42-47.

[16] Pohuang, T., Chansiripornchai, N., Tawatsin, A. , Sasipreeyajan, J.,2009.Detection and molecular characterization of infectious bronchitis virus isolated from recent outbreaks in broiler flocks in Thailand. Journal of Veterinary Science 10, 219-223.

[17] Rafiei, M.M.,Vasfi-Marandi, M.,Bozorgmehri-Fard, M.H. , Ghadi, S.,2009.Identification of Different Serotypes of Infectious Bronchitis Viruses in Allantoic Fluid Samples with Single and Multiplex RTPCR.Iranian Journal of Virology 3, 24-29.

[18] Roussan, D. A.,Totanji, W. S. ,Khawaldeh, G. Y.,2008. Molecular Subtype of Infectious Bronchitis Virus in Broiler Flocks in Jordan. Poultry Science 87, 661-664.

[19] Selima,K., Arafa, A.S., Hussein, H.A., El-Sanousi, A.A. 2012. Molecular characterization of infectious bronchitis viruses isolated from broiler and layer chicken farms in Egypt during 2012.International journal of Veterinary Science and Medicine 1, 102-108

[20] Vabret, A., Sapin, G., Lezin, B., Mosnier, A., Cohen, J., Burnouf, L .,Petitjean, J., Gouarin, S., Campet, M. , Freymuth, F.,2000.Comparison of three non-tested RT-PCR for detection of influenza American Journal of Clinical Virology, 17, 167-75 .

[21] Xie,Q., Ji, J., Xie,J., Chen,F.,Cai,M.,Xue,C.,Мa,J., Bi,Y.,2011.Epidemiology and immunoprotection of nephropathogenic avian infectious bronchitis virus in southern ChinaVirology Journal, 8, 484.

[22] Yashpal, S.M., Devi, P.P., Sagar, M.G., 2004. Detection of three avian respiratory viruses by singletube multiplex reverse transcription polymerase chain reaction assay. Journal of Veterinary Diagnostic Investigation, 16, 244-248. 